\title{
Development of Dyadic Relationship Scale
} Özlem HASKAN AVCI ${ }^{*}$

\section{Suggested Citation:}

Haskan Avc1, Ö. (2014). Development of dyadic relationship scale. Eurasian Journal of Educational Research. , 56, 1-24DOI: http://dx.doi.org/10.14689/ejer.2014.56.6

\begin{abstract}
Problem Statement: The rise of premarital studies brings along questions about the evaluation of effectiveness of educational programs developed for preparing young individuals for marriage and family life.
\end{abstract}

Purpose of Study: The purpose of this study is to develop Dyadic Relationship Scale for university students. This study introduces Dyadic Relationship Scale (DRS) developed on the basis of Turkish culture.

Methods: Validity and reliability studies for the DRS were conducted with the participation of 1115 students of Hacettepe University, Ankara, Turkey. The data obtained were analyzed by the SPSS software. Construct validity of the DRS was examined with the exploratory factor analysis. The DRS prepared is five point Likert scale having five subscales and 78 items. The five subscales are Communication, Romanticism-Sexuality, Conflict Solving, Social Support, and Acceptance of Differences.

Findings and Results: The Communication subscale displays a 6-factor structure and explains $64.2 \%$ of the total variance, while the RomanticismSexuality subscale displays a 5 -factor structure and explains $61.5 \%$ of the total variance, the Conflict Solving subscale displays a 5-factor structure and explains $60.1 \%$ of the total variance, the Social Support subscale displays a 2-factor structure and explains $63.3 \%$ of the total variance and the Acceptance of Differences subscale displays a 5-factor structure and explains $60.7 \%$ of the total variance. On the other hand, criterion-related validity was analyzed between the DRS and the Pre-Marital Relationship Assessment Scale. Based on the data obtained from 181 university students, a positive and significant correlation at the level of .824 was determined between two scales. Reliability of the DRS was analyzed in two ways. Firstly, Cronbach alpha coefficient was calculated for all subscales of the DRS. Alpha coefficients were calculated to be .77 for the Communication subscale, .88 for the Romanticism-Sexuality subscale, .85 for the Conflict Solving subscale, .91 for the Social Support subscale and .79 for the Acceptance of Differences subscale. Secondly, reliability

* Dr. Hacettepe Üniversitesi, Eğitim Fakültesi, Psikolojik Danışma ve Rehberlik Anabilim Dalı, e-mail.haskan@hacettepe.edu.tr 
coefficients of the DRS, which were analyzed by use of the split-half method, were found to be .61 for the Communication subscale, .64 for the Romanticism-Sexuality subscale, .73 for the Conflict Solving subscale, .69 for the Social Support subscale and .64 for the Acceptance of Differences subscale.

Conclusions and Recommendation: Evidences reached for validity and reliability show that the DRS can be validly and reliably used for measuring dyadic relationship levels among university students. Premarital educators can use the DRS in evaluating the effectiveness of their practices.

Keywords: dyadic relationship, premarital relationship, premarital counseling, marriage preparation programs

\section{Introduction}

Family, an important building stone of the society, plays a significant role in raising healthy individuals and creating a stronger society. In this point, marriage is one of the most important and serious steps in establishing a family (Dinçyürek \& Uygarer, 2012). When the studies conducted on marriage and family in Turkey and around the world are viewed, divorce rates are seen to be frequently addressed. According to the data of the Turkish Statistics Institution (TUIK), number of divorces in the first half of 2012 increased by $5.8 \%$ when compared to the same period of the previous year, and reached to 33,474 (TÜIKK, 2012). Increasing year by year, number of divorces creates the impression that couples are not able to reach their expectations from marriage. Experts continuously try to bring premarital relationships to the attention of the public, educators and the politicians, and emphasize the importance of preventative works in line with the purpose of lowering the rate of divorce, since several researches reveal that the rate of divorce is $30 \%$ lower among couples who attend to and complete marriage preparation programs (Stanley, Amato, Johnson \& Markman, 2006).

No doubt, it is a process for couples to reach to the point of deciding divorce. High numbers of divorce suggest that certain problems may become unsolvable in time for couples. In the context of these problems, researchers point to the connections between divorces and the premarital period. Factors influencing marriage decisions are possible to cause both problems and positive results during marriage (Dinçyürek \& Uygarer, 2012). According to Kalkan and Yalçın (2012), the premarital period may be misleading for both parties and individuals may tend to present only positive sides of their personalities and overlook negative properties of their partners. Keitner, Heru and Glick (2010) point out that being closed to recognizing each other's differences in a relationship may result in a tendency to suppress differences, which may in turn create disappointments and conflicts. Partners who do not accept each other as is generally experience more problems. 
Constraints affecting young individuals in preparation to marriage and family life are also considered as a subject of research. According to Olson and DeFrain (1994), engaged couples may develop an idealistic point of view for the future marriage. In general, problems immediately occur when the first romantic phase of love comes to an end. In this point, counseling is capable of helping couples in renewing and reviewing their relationships (Peake \& Steep, 2005). On the other hand, studies conducted on marriage show us that therapies applied for damaged marriages present a very low rate of success. We have several findings which reveal that marriage counseling is considered to be quite costly and that many couples experiencing marriage stress do not seek for support, or seek for it after a considerable span of time (Sullivan, Pasch, Cornelius \& Cirigliano, 2004). According to Bringle and Byers (1997), couples unfortunately receive counseling not as a preventative measure before problems arise, but after several problems develop and reach a serious extent. A low rate of success is highly possible for couples who seek for marriage and family counseling at a very late stage.

These outcomes reflect the importance of the preventative dimension of marriage and family counseling, as is the case for many other fields included counseling and guidance. While rates and negative effects of divorce are frequently mentioned, researches and education programs which draw attention to the importance of premarital relationship in prevention of divorce and providing a healthy family life are too limited. Early intervention and support is known to be effective in orienting young individuals to marry only after establishing a strong relationship, improve loyalty and reduce the risks for a problematic relationship and in ensuring that individuals adopt realistic expectations, reach a higher understanding of marital roles and problems arising during marriage, develop marital communication and problem solving skills (Silliman \& Schumm, 2004).

In Turkish society, which attaches great importance to the wedding day, it is necessary to divert the attention of people to marriage, a very important period of life, and to premarital counseling programs. The same seems to apply to the American society, and Britzman and Nagelhout (2012) accordingly report that people generally allocate too little time to search what is waiting for them in their future marriage. It is particularly important for individuals to seek the answer to the question "How is it to marry me?" before deciding for it.

A common side of the international studies conducted on premarital relationships is the emphasis put on the importance of communication and conflict solving. Doherty (2003) states that premarital counseling is important in addressing major issues of married life, which are listed as couple communication, problems solving techniques, loyalty, sexual desire and expectations, economical structure and financial management, and parenting approach. When the literature is viewed, significance of romanticism and sexuality, acceptance of differences as is and the support presented to each other is clearly seen. Researches show us that premarital education has become widespread in the last 50 years and that couples who attend to and complete a premarital program have higher quality of marriage, lower level of conflict and 30\% lower rate of divorce (Stanley, Amato, Johnson \& Markman, 2006). 
Marriage preparation and enhancement programs, premarital counseling and other preventative measures help in building a stronger marriage and reduce the marriage stress (Lesage-Higgins, 1999).

In Turkey, premarital education is seen to be addressed at the ministry level in recent years. The Ministry of Family and Social Policies' statement which said "Just like the need to complete a course for receiving driving license, the same may apply for marriage" created repercussions in the media about the importance of the issue. "Marriage preparation courses" were organized and realized through the evaluation that "The way of strengthening the institution of marriage passes from premarital courses," (The Ministry of Family and Social Policies, 2013).

The rise of such practices brings along questions about the evaluation of effectiveness of educational programs developed for preparing young individuals for marriage and family life. The needs for scientific, valid and reliable measuring instruments that can be used in evaluating such programs become apparent. When previous works carried out in Turkey are reviewed, number of measuring instruments tested in terms of validity and reliability, which can be used in evaluating the effectiveness of premarital counseling programs are seen to be limited.

Although long standing premarital counseling programs and measuring instruments can be found when international studies are reviewed, dyadic relationships are known to differ based on the cultural background, local conditions and social group structures. From this point of view, it was decided to develop a new instrument for measuring various aspects of dyadic relationships under the specific conditions of our own country, instead of trying to adopt a scale developed on the basis of a different culture. Larson et al. (1995) suggest that premarital measurements must be strong enough in five particular subjects: being designed mainly or specifically for measuring premarital relationships; being able to ensure that comprehensive data are obtained about the educational process; being able to be applied on a large scale; being easy to be understood; and lastly, being proven to be valid and reliable. In this study, which took these criteria into consideration, it was aimed to develop a Dyadic Relationship Scale for measuring various aspects of relationships among university students and to contribute in filling a gap in the literature.

\footnotetext{
Method

Participants

For determining the validity and reliability of the DRS, firstly a trial form consisting of 85 items was applied on 52 students of the university, and items which were found to be inexplicable were rearranged afterwards. Validity and reliability works by use of the final DRS form were performed with the participation of 678 randomly selected Hacettepe University students, 376 of whom were female (55.5\%) and 302 were male (44.5\%). In addition, split-half reliability and criterion-related validity analyzes were carried out on 204 and 181 students of the university respectively. In total, 1115 university students contributed to the development of the Dyadic Relationship Scale.
} 
Procedure

In order for the Dyadic Relationship Scale to be developed, firstly a literature review was performed, and five subscales and an items pool of 88 items were established by determining the feelings, thoughts and behaviors of university students on premarital relationship. The five subscales included under the DRS are Communication, Romanticism-Sexuality, Conflict Solving, Social Support and Acceptance of Differences. Perceived Social Support Scale (Yildırım, 2004) was used in the establishment of the Social Support subscale. After the arrangements made on the items pool in line with the suggestions provided by three experts from the field of counseling and guidance, three of the items were removed and a trial form consisting of 85 items was prepared. In consequence of the implementation of the trial form, items found to be inexplicable were rearranged. At the next stage, validity and reliability studies were conducted on the DRS with the data collected from 678 students. As a result, number of items in the final form of the DRS was reduced to 78 . For testing the validity of the scale, criterion-related validity was analysed between the DRS and the Pre-Marital Relationship Assessment Scale. Cronbach alpha coefficients and item/total statistics of the scale were reviewed for determining reliability coefficients of the scale and split-half reliability method was applied as well.

Instruments and Procedure

Pre-Marital Relationship Assessment Scale (PMRAS) (Kalkan \& Nevres Kaya, 2007) was employed for reviewing criterion-related validity of the DRS. While the two scales present similarities in terms of the qualifications intended to be measured and the study groups, there are differences related to the sub-dimensions measured. PMRAS is a scale with 34 items and five grades. There are five factors included in the scale, which explains $42.9 \%$ of the total variance. The correlation coefficient between the scores of PMRAS and the Relationship Happiness Scale was found to be .48 $(\mathrm{p}<.01)$, while internal consistency coefficient for the whole PMRAS (Cronbach alpha) was calculated to be .86 . Besides, test-retest reliability coefficient calculated on 64 individuals' PMRAS scores was .72 ( $\mathrm{p}<.01)$.

Data Analysis

The SPSS software was employed for data analysis. Firstly, it was considered that KMO must be higher than 0.60 and the Barlett test must provide significant results in order for the data to be deemed suitable for a factor analysis (Büyüköztürk, 2004). After it was determined that the data were suitable for carrying out a factor analysis, factor structure of the scale and factor loading of the items were examined by use of the exploratory factor analysis. Meanwhile, principal components analysis (PCA) was selected to be applied as the factoring technique. Common factor variance of the factors on each variable, factor loadings of items and explained variance proportions were examined within the scope of the analyses. Having a factor loading value of .30 or higher was taken as a criterion in determining factor structures of the items. The items were required to have a factor loading of 0.30 or higher for the first factor, and each subscale was required to be one-dimensional and provide a usable total score in the component matrix table (Büyüköztürk 2004). Varimax rotation technique was selected to be used in order to ensure that interrelated items form factors by 
combining and the factors are construed easily. As a result of the analyses, items which have factor loading values lower than 0.30 for the first factor, or have similar factor loading values for several factors and provide little distinctiveness, or present weak correlation with other items of the scale were removed from the scales. Validity of the DRS was also checked by use of the criterion-related validity method and the Pearson correlation coefficient was analyzed between the DRS and the Pre-Marital Relationship Assessment Scale (PMRAS). Cronbach alpha coefficients and item/total correlation values of the scale were reviewed for evaluating the scale's reliability.

Validity of the DRS

\section{Results}

In this study, validity of the DRS was examined in two ways. Firstly, a factor analysis was performed in order to reveal the structural validity of the DRS. The KMO coefficient and explained total variance were studied for all subscales of the DRS. In factor analysis, factors with an eigenvalue of 1 or higher are considered to be significant (Büyüköztürk 2004). Based on this consideration, factor structures were examined separately for each subscale, and factor analysis results belonging to the subscales are addressed in this section of the study.

Factor analysis results for the communication subscale. The "Communication" subscale of the DRS consisted of 15 items. The KMO coefficient was calculated to be .77 and the result of the Barlett test was significant for this subscale.

Table 1.

Factor Analysis Results for the Communication Subscale of the DRS

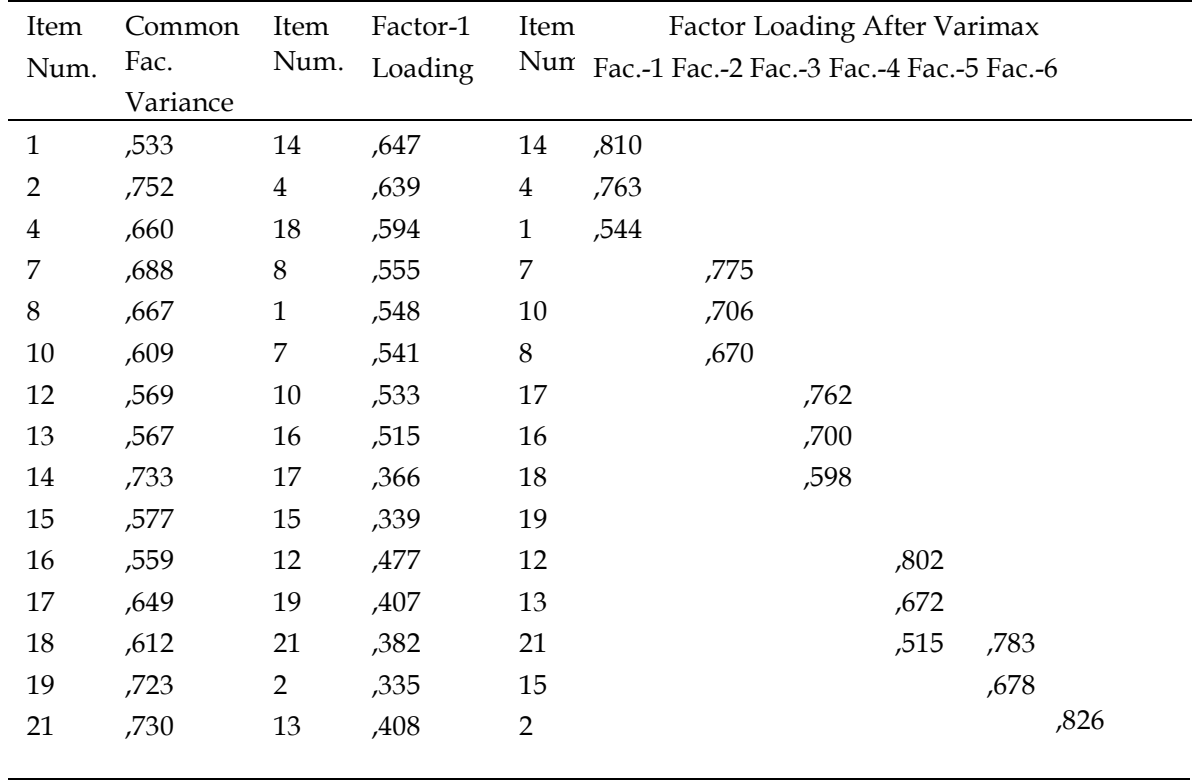

Explained Variance: Total: \% 64,19 Factor-1: \% 24,64 Factor-2: \% 9,56

Factor-3: \% 9,03 Factor-4: \% 7,30 Factor-5: \% 6,93 Factor-6: \% 6,73 
Common factor variance of the factors on each variable was found to range from .533 to .733 . The Communication subscale presented a structure of 6-factors with eigenvalues higher than 1 . The six factors explained $64.19 \%$ of the total variance together. Calculated variance percentages explained by the first, second, third, fourth, fifth and sixth factors were 24.64, 9.56, 9.03, 7.30, 6.93 and 6.73 respectively. Factor loadings of the items (component matrix) were seen to vary between .335 and .647 at the first factor.

As a result of the varimax rotation technique, the first factor was determined to consist of three items $(1,4,14)$; the second to consist of three items $(7,8,10)$; the third to consist of three items $(16,17,18)$; the fourth to consist of three items $(9,12,13)$; the fifth to consist of two items $(15,21)$; and the sixth factor was determined to consist of only one item (2). Factors were named in consideration of the contents of the items. Thus, the first factor was named as "verbal offence"; the second as "self regulation"; the third as "self control"; the fourth as "manipulation"; the fifth as "sharing and coupling"; and the sixth factor was named as "tiring out".

Factor analysis results for the romanticism-sexuality subscale. The "RomanticismSexuality" subscale of the DRS consisted of 18 items. The KMO coefficient was calculated to be .89 and the result of the Barlett test was significant for this subscale.

Table 2.

Factor Analysis Results for the Romanticism-Sexuality Subscale of the DRS

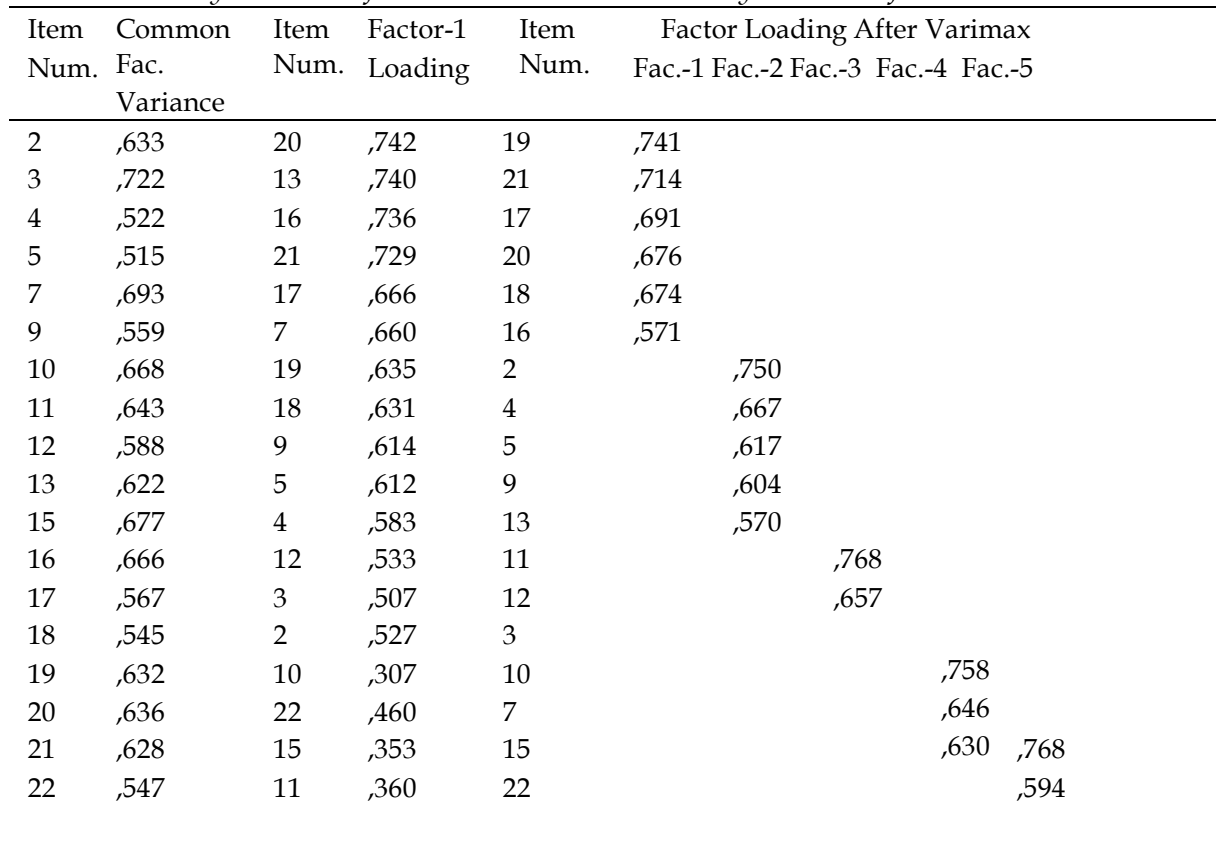

Explained Variance: Total: \% 61,46 Factor-1: \% 35,12 Factor-2: \% 8,16

Factor-3: \% 6,56 Factor-4: \% 6,02 Factor-5: \% 5,61 
As a result of the varimax rotation technique, the first factor was determined to consist of 6 items $(16,17,18,19,20,21)$; the second factor was determined to consist of five items $(2,4,5,9,13)$; the third factor was determined to consist of two items $(11,12)$; the fourth factor was determined to consist of three items $(3,7,10)$; and the fifth factor was determined to consist of two items $(15,22)$. Factors were named in consideration of the contents of the items. Thus, the first factor was named as "romanticism behaviors"; the second factor was named as "relationship saturation"; the third factor was named as "physical intimacy"; the fourth factor was named as "romanticism perception"; and the fifth factor was named as "romanticism expectation".

Factor analysis results for the conflict solving subscale. The "Conflict Solving" subscale of the DRS consisted of 18 items. The KMO coefficient was calculated to be .86 and the result of the Barlett test was significant for this subscale.

Table 3.

Factor Analysis Results for the Conflict Solving Subscale of the DRS

\begin{tabular}{|c|c|c|c|c|c|c|c|c|c|}
\hline \multirow{2}{*}{$\begin{array}{l}\text { Item } \\
\text { Num. }\end{array}$} & \multirow{2}{*}{$\begin{array}{l}\text { Common } \\
\text { Fac. } \\
\text { Variance }\end{array}$} & \multirow{2}{*}{$\begin{array}{l}\text { Item } \\
\text { Num. }\end{array}$} & \multirow{2}{*}{$\begin{array}{l}\text { Factor-1 } \\
\text { Loading }\end{array}$} & \multirow{2}{*}{$\begin{array}{l}\text { Item } \\
\text { Num. }\end{array}$} & \multicolumn{5}{|c|}{ Factor Loading After Varimax } \\
\hline & & & & & Fac.-1 & Fac.-2 & Fac.-3 F & Fac.-4 & Fac.-5 \\
\hline 1 & ,566 & 24 & 679 & 21 & 752 & & & & \\
\hline 4 &, 590 & 5 & 662 & 13 & 691 & & & & \\
\hline 5 & 618 & 20 & 629 & 24 & 687 & & & & \\
\hline 6 & 607 & 4 & ,575 & 20 & 645 & & & & \\
\hline 8 & ,511 & 11 & ,574 & 18 & ,511 & & & & \\
\hline 9 & 671 & 21 & 561 & 22 & & 772 & & & \\
\hline 10 & 720 & 8 & 537 & 15 & & 760 & & & \\
\hline 11 & 620 & 23 & 526 & 17 & & 680 & & & \\
\hline 12 & 614 & 9 & ,507 & 23 & & ,552 & & & \\
\hline 13 & 644 & 17 & ,502 & 4 & & & 710 & & \\
\hline 15 & 608 & 18 & ,457 & 5 & & & 701 & & \\
\hline 17 &, 533 & 22 & 419 & 11 & & & 696 & & \\
\hline 18 &, 509 & 10 &, 510 & 8 & & & 634 & & \\
\hline 20 &, 548 & 15 & 395 & 9 & & & & 789 & \\
\hline 21 & 696 & 13 & ,524 & 10 & & & & 774 & \\
\hline 22 & 668 & 1 & ,411 & 1 & & & & 709 & \\
\hline 23 & 492 & 12 & ,456 & 12 & & & & & 626 \\
\hline 24 & 603 & 6 & 523, & 6 & & & & & 533, \\
\hline
\end{tabular}

Explained Variance: Total: \% 60,1 Factor-1: \% 28,17 Factor-2: \% 13,08

Factor-3: \% 6,94 Factor-4: \% 6,14 Factor-5: \% 5,76

Common factor variance of the factors on each variable was found to range from .509 to .720 . The Conflict Solving subscale presented a structure of five factors with eigenvalues higher than 1 . The five factors explained $60.1 \%$ of the total variance together. Calculated variance percentages explained by the first, second, third, fourth 
and fifth factors were 28.17, 13.08, 6.94, 6.14 and 5.76 respectively. Factor loadings of the items (component matrix) were seen to vary between .395 and .679 at the first factor.

As a result of the varimax rotation technique, the first factor was determined to consist of 5 items $(13,18,20,21,24)$; the second factor was determined to consist of four items $(15,17,22,23)$; the third factor was determined to consist of four items $(4$, $5,8,11)$; the fourth factor was determined to consist of three items $(1,9,10)$; and the fifth factor was determined to consist of 2 items $(6,12)$. Factors were named in consideration of the contents of the items. Thus, the first factor was named as "tendency of nonconflicting"; the second factor was named as "self control"; the third factor was named as "power struggle"; the fourth factor was named as "aiming at solutions"; and the fifth factor was named as "implicit conflict".

Factor analysis results for the social support subscale. The "Social Support" subscale of the DRS consisted of twelve items. The KMO coefficient was calculated to be .92 and the result of the Barlett test was significant for this subscale.

Table 4.

Factor Analysis Results for the Social Support Subscale of the DRS

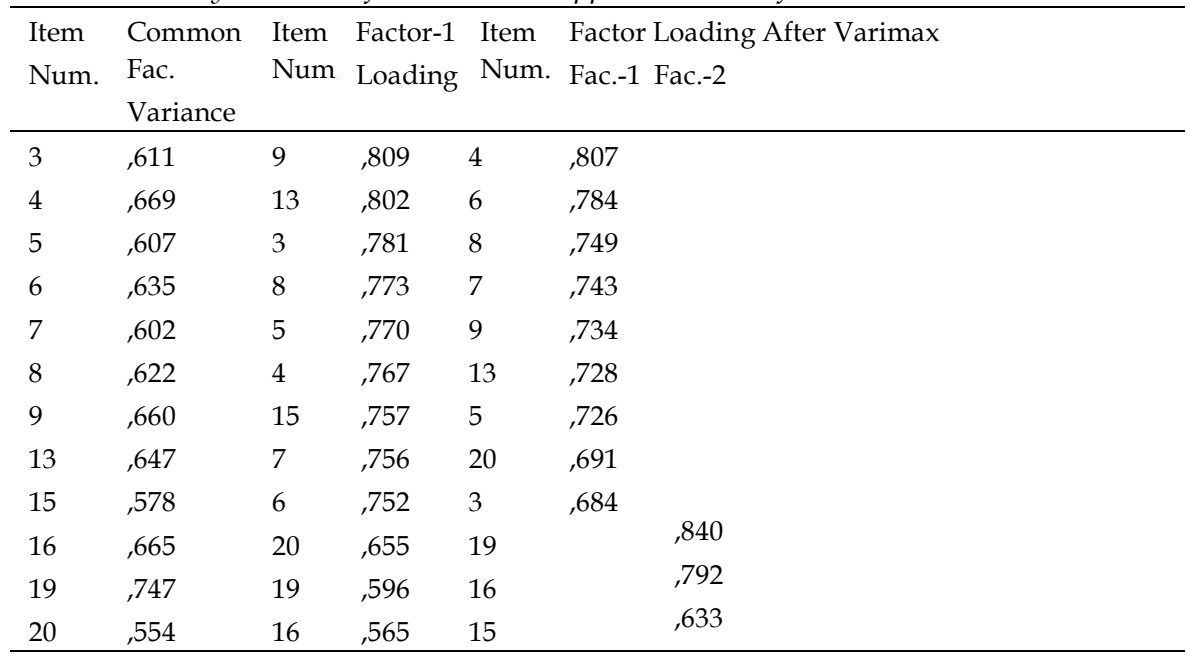

Explained Variance: Total: \% 63,32 Factor-1: \% 54,16 Factor-2: \% 9,16

Common factor variance of the factors on each variable was found to range from .554 to .747 . The Social Support subscale presented a structure of two factors with eigenvalues higher than 1 . The two factors explained $63.32 \%$ of the total variance together. Calculated variance percentages explained by the first and second factors were 54.16 and 9.16 respectively. Factor loadings of the items (component matrix) were seen to vary between .565 and .809 at the first factor.

As a result of the Varimax rotation technique, the first factor was determined to consist of 9 items $(3,4,5,6,7,8,9,13,20)$; and the second factor was determined to 
consist of three items $(15,16,19)$. Factors were named in consideration of the contents of the items. Thus, the first factor was named as "emotional support"; and the second factor was named as "appreciating".

Factor analysis results for the acceptance of differences subscale. The "Acceptance of Differences" subscale of the DRS consisted of fifteen items. The KMO coefficient was calculated to be .81 and the result of the Barlett test was significant for this subscale.

Table 5

Factor Analysis Results for the Acceptance of Differences Subscale of the DRS

\begin{tabular}{|c|c|c|c|c|c|c|c|c|c|}
\hline \multirow{2}{*}{$\begin{array}{l}\text { Item } \\
\text { Num. }\end{array}$} & \multirow{2}{*}{$\begin{array}{l}\text { Common } \\
\text { Fac. } \\
\text { Variance }\end{array}$} & \multirow{2}{*}{$\begin{array}{l}\text { Item } \\
\text { Num. }\end{array}$} & \multirow{2}{*}{$\begin{array}{l}\text { Factor-1 } \\
\text { Loading }\end{array}$} & \multirow{2}{*}{$\begin{array}{l}\text { Item } \\
\text { Num. }\end{array}$} & \multicolumn{5}{|c|}{ Factor Loading After Varimax } \\
\hline & & & & & Fac.-1 & Fac.-2 & Fac.-3 & Fac.-4 $\mathrm{I}$ & Fac. -5 \\
\hline 2 & ,504 & 12 & 667 & 8 & 856 & & & & \\
\hline 3 & 607 & 11 & ,636 & 12 & 796, & & & & \\
\hline 4 & ,460 & 9 & ,589 & 9 & 609, & & & & \\
\hline 5 & ,713 & 7 & 566 & 18 & & 754 & & & \\
\hline 7 & 520 & 18 & 536 & 16 & & 747 & & & \\
\hline 8 & 754 & 3 & 511 & 13 & & 686 & & & \\
\hline 9 &, 597 & 14 &, 509 & 5 & & & ,837 & & \\
\hline 10 & 686 & 8 &, 505 & 3 & & & 734 & & \\
\hline 11 & 522 & 13 & 491 & 2 & & & 629 & & \\
\hline 12 & 761 & 2 & 461 & 10 & & & & 806 & \\
\hline 13 & 522 & 5 & 414 & 7 & & & & 652 & \\
\hline 14 & 645 & 16 & 440 & 11 & & & &, 526 & \\
\hline 16 & ,596 & 4 & 402 & 20 & & & & & \\
\hline 18 & 631 & 20 & 384 & 14 & & & & & 738, \\
\hline 20 &, 590 & 10 & 539 & 4 & & & & & 706 \\
\hline & & & & & & & & & 495 \\
\hline
\end{tabular}

Explained Variance: Total: \% 60,7 Factor-1: \% 26,65 Factor-2: \% 11,43

Factor-3: \% 8,85 Factor-4: \% 7,06 Factor-5: 6,73

Common factor variance of the factors on each variable was found to range from .504 to .761. The Acceptance of Differences subscale presented a structure of 5-factors with eigenvalues higher than 1 . The five factors explained $60.7 \%$ of the total variance together. Calculated variance percentages explained by the first, second, third, fourth and fifth factors were 26.65, 11.43, 8.85, 7.06 and 6.73 respectively. Factor loadings of the items (component matrix) were seen to vary between .384 and .667 at the first factor.

As a result of the Varimax rotation technique, the first factor was determined to consist of three items $(8,9,12)$; the second factor was determined to consist of three items $(13,16,18)$; the third factor was determined to consist of three items $(2,3,5)$; the fourth factor was determined to consist of three items $(7,10,11)$; and the fifth factor was determined to consist of three items $(4,14,20)$. Factors were named in consideration of the contents of the items. Thus, the first factor was named as "acceptance of socioeconomic differences"; the second factor was named as 
"acceptance of personal differences"; the third factor was named as "acceptance of personal preference differences"; the fourth factor was named as "sense of belonging"; and the fifth factor was named as "respect".

High loading values at the first factor of the items before the rotation, the high percentage of variance explained by the first factor and the rapid decrease seen on the line chart after the first factor suggest that the subscales also have a common factor. The literature says us that loading values of .45 or higher for the items is a positive criterion for the selection; however the limit value can be.30 for a little number of items in practice (Büyüköztürk, 2004). While the subscales of the DRS were limited in quantity, there was no item with a factor loading value lower than .30 .

\section{Criterion-Related Validity of the DRS}

Validity of the DRS was analyzed by use of the "Criterion-related validity" method as well. The DRS and the Premarital Relationship Assessment Scale were applied together on 181 Hacettepe University students. Pearson correlation coefficients for the scales are shown in Table 6.

Table 6

The Correlation between the DRS and its Subscales and the PMRAS

\begin{tabular}{llllllll}
\hline & COM & RS & CS & SS & AD & DRS & PMRAS \\
\hline COM & 1,00 & & & & & & \\
RS &, $923^{* *}$ & 1,00 & & & & & \\
CS &, $967^{* *}$ &, $966^{* *}$ & 1,00 & & & & \\
SS &, $725^{* *}$ &, $881^{* *}$ &, $808^{* *}$ & 1,00 & & & \\
AD &, $935^{* *}$ &, $977^{* *}$ &, $977^{* *}$ &, $837^{* *}$ & 1,00 & & \\
\hline DRS &, $963^{* *}$ &, $987^{* *}$ &, $991^{* *}$ &, $856^{* *}$ &, $988^{* *}$ & 1,00 & \\
\hline PMRAS &, $797^{* *}$ &, $804^{* *}$ &, $811^{*}$ &, $727^{*}$ &, 815 &, $824^{* *}$ & 1,00 \\
\hline
\end{tabular}

$\mathrm{COM}=$ Communication, $\mathrm{RS}=$ Romanticism - Sexuality, $\mathrm{CS}=$ Conflict Solving,

$\mathrm{SS}=$ Social Support, $\mathrm{AD}=$ Acceptence of Difference, DRS= Dyadic Relationship Scale,

PMRAS= Premarital Relationship Assessment Scale

${ }^{* *}$ Correlation is significant at 0.01 level

* Correlation is significant at 0.05 level

As can be seen on Table-6, there are positive and significant correlations between the DRS and its subscales and the PMRAS. These correlations can be considered as 
the evidences of the validity of the DRS and its subscales. The two methods implemented for evaluating the validity of the DRS both revealed positive results.

Reliability of the DRS

Reliability of the DRS was calculated in two ways. Firstly, Cronbach alpha coefficient was analyzed for all subscales of the DRS. Alpha coefficients were calculated to be .77 for the Communication subscale, .88 for the RomanticismSexuality subscale, .85 for the Conflict Solving subscale, .91 for the Social Support subscale and .79 for the Acceptance of Differences subscale. According to the literature, reliability coefficients of .70 or higher are considered to be sufficient in terms of reliability in the interpretation of Cronbach alpha scores. Secondly, split-half reliability coefficients of the DRS were found to be .61 for the Communication subscale, .64 for the Romanticism-Sexuality subscale, .73 for the Conflict Solving subscale, .69 for the Social Support subscale and .64 for the Acceptance of Differences subscale. Split-half coefficients of the DRS are seen to be in compliance with the values expected by the literature. Evidences reached for validity and reliability show that the DRS can be validly and reliably used for measuring dyadic relationship levels among university students.

\section{Scoring of the DRS}

Items included in the scope of the DRS were grouped in subscales. Total number of items of the DRS is 78, 15 of which is included in the Communication subscale, 18 in the Romanticism-Sexuality subscale, 18 in the Conflict Solving subscale, 12 in the Social Support subscale and the remaining 15 in the Acceptance of Differences subscale. All subscales also have reverse items. Three grades were present for the scale (completely fits me $=3$, does not fit me at all $=1$ ), and the students were requested to put a cross in the parentheses of relevant grade. Direct items were scored with their mentioned points, while reverse items were scored contrarily. Score ranges for the subscales and the scale itself are 15-45 for Communication; 18-54 for Romanticism-Sexuality; 18-57 for Conflict Solving; 12-36 for Social Support; 15-45 for Acceptance of Differences; and 78-234 for the whole DRS. Higher scores indicate a more positive dyadic relationship for the individual in relation with the relevant subscale.

\section{Discussion and Conclusions}

Evidences reached for validity and reliability show that the DRS can be validly and reliably used for measuring dyadic relationship levels among university students. However, in order for the DRS to be capable of measuring dyadic relationships of individuals from other age groups, necessary validity and reliability works must be performed for the scale. A limitation of the study is that it was not always possible to apply the scale on both partners simultaneously. The DRS was observed to measure various factors including but not limited to verbal offence, self regulation, self control, manipulation, sharing and coupling, romanticism behaviors, physical intimacy, romanticism perception, tendency of nonconflicting, power struggle, aiming at solutions, implicit conflict, emotional support, appreciating, 
acceptance of socioeconomic differences and acceptance of personal differences. On the other hand, other instruments can be developed for measuring additional factors of dyadic relationship for university students, which are not included in the scope of this study.

As it was mentioned in the introduction section, premarital programs gradually become widespread in Turkey and several researches show that healthy dyadic relationship is a prerequisite for healthy marriages. It is not a realistic approach to think that the problems experienced during the dyadic relationship will come to an end with the wedding ceremony. On the contrary, problems which are not solved during the dyadic relationship tend to continue after marriage and may even break marriages by creating a snowball effect. Premarital counseling rather significant in its capability for both preparing the partners for a healthier marriage and preventing the negative and costly effects of divorces on individuals, families and the society (Carroll \& Doherty, 2003). It is seen that different measuring instruments are needed in supporting the proliferation of premarital programs and making evaluations on marriage preparation programs. In line with this need, implementers of premarital counseling and marriage preparation programs can use the DRS in evaluating the effectiveness of their practices. The DRS can be particularly used in the implementation of marriage preparation programs targeting university students as pre-post tests. When the empirical studies conducted in the field of counseling and guidance are reviewed, premarital psycho-educational programs are understood to be able to be efficient (Duran; 2010; Yalçın, 2010; Y1lmaz \& Kalkan, 2010).

An additional benefit can be created by determining the students who experience problems in their dyadic relationships and ensuring that they receive individual and group therapy support from counseling centers of universities. The DRS can be also used especially by counselors, couple and family counselors, psychologists, psychiatrists, social service specialists and researchers through their own objectives. Results of the scale are thought to be beneficial particularly for couple therapy specialists in implementing therapy processes. 


\section{References}

Aile ve Sosyal Politikalar Bakanlığı ([ASPB], (2013). Evlilik Öncesi Eğitim Programı. Retrieved February 92013 from

http://tv.aile.gov.tr/tr/html/1934/Evlilik-Oncesi-Egitim-Programi

Bringle, R. \& Byers, D. (1997). Intentions to seek marriage counseling. Family Relations, 46, 299-304.

Büyüköztürk, Ş. (2004). Sosyal bilimler için veri analizi el kitabı. [Data Analysis and SPSS Practices for Social Science] Ankara: Pegem-A Yayınları.

Carroll, J. S. ve Doherty, W. J. (2003). Evaluating effectiveness of premarital prevention programs: a meta-analytic review of outcome research. Family Relations, 52(2):105-118.

Dinçyürek, S., Uygarer, G.. (2012). The role of communication skills on perspectives of university students about marriage during dating (emotional friendship). Eğitim Araştırmaları-Eurasian Journal of Educational Research, 49/ A, 151-166.

Duran, Ş. (2010). Evlilik öncesi ilişki geliştirme programının romantik ilişkiler yaşayan üniversite öğrencilerinin iletişim becerileri, çatışma iletişim tarzlar ve ilişki istikrarlar üzerine etkisinin incelenmesi. [The investigation of effects of premarital relationships enhancement program on relationship stability, conflict communication styles and communication skills of university students with romantic relationship]. Unpublished master thesis, Gaziantep: Gaziantep Üniversitesi.

Kalkan, M., Hamamcı, Z.,Yalçın, İ. (2012). Evlilik öncesi psikolojik danışma. [Premarital Counseling]. Ankara: Anı Yayıncılık.

Keitner, G, Heru, A \& Glick, I. (2010). Clinical manual of couples and family therapy. Washington DC: Guilford Press.

Larson, J.H., Holman, T.B., Klein, D.M., Busby, D.M., Stahmann, R.F., Peterson, D. (1995). A review of comprehensive questionnaires used in premarital education and counseling. Family Relations, 44, 245-252.

Lesage-Higgins, S. A. (1999). Family sculpting in premarital counseling. Family Therapy, 26, 31-38.

Olson, D. H., \& DeFrain, J. (1994). Marriage and the family: Diversity and strengths, Mountain View, CA: Mayfield.

Peake, T.H. \& Steep, A.E. (2005). Therapy with older couples: love stories - the good, the bad, and the movies. In Michelle Harway (Eds), Handbook of couples therapy, (pp. 80-99), Canada: John Wiley \&Sons.

Silliman, B. \& Schumm, W.R. (2000). Marriage preparation programs: a literature review. The family journal: Counseling And Therapy For Couples And Families, 8 (2), 133-142. 
Stanley, S.M., Amato, P.R., Johnson, C.A., \& Markman, H.J. (2006). Premarital education, marital quality and marital stability: findings from a large, random household survey. Journal of Family Psychology, 20 (1), 117-126.

Sullivan, K. T., Pasch, L. A., Cornelius, T., \& Cirigliano, E. (2004). Predictors of participation in premarital prevention programs: the health belief model and social norms. Family Process, 43, 175-194.

Türkiye İstatistik Kurumu ([TÜİK], 2012). Evlenme ve Boşanma İstatistikleri, 1. Dönem 2012 Retrieved: March 302012 from

http:/ / www.tuik.gov.tr/PreHaberBultenleri.do?id=10849

Yalçın, İ. (2010). İlişki geliştirme programının üniversite öğrencilerinin ilişki doyum düzeylerine etkisi. [The effectiveness of the relationship enhancement program on relationship satisfaction of university students]. Unpublished doctoral dissertation, Ankara: Hacettepe Üniversitesi.

Yılmaz, T. \& Kalkan, M. (2010). Evlilik öncesi ilişki geliştirme programının çiftlerin ilişki doyumuna etkisi. [The effects of a Premarital Relationship Enrichment Program on relationship satisfaction]. Kuram ve Uygulamada Eğitim Bilimleri, 10 (3), 1893-1920.

\section{Çift İlişkileri Ölçeği'nin Geliştirilmesi}

(Özet)

Atıf:

Haskan Avc1, Ö. (2014). Development of dyadic relationship scale. Eurasian Journal of Educational Research. , 56, 1-24DOI: http://dx.doi.org/10.14689/ejer.2014.56.6

\section{Problem durumu}

Sağlıklı bir toplum sağlıklı ailelerden oluşur. Sağlıklı ailelerin varlı̆̆ı temelde sağlıklı ve işlevsel çift ilişkilerine dayanmaktadır. Türkiye' de ve dünya genelinde evlilik ve aile ile ilgili araştırmalar incelendiğinde, sıklıkla dikkat çekilen konunun boşanma oranları olduğu görülmektedir. Uzmanlar, boşanmaların azaltılabilmesi için halkın, eğitimcilerin ve politikacıların dikkatini evlilik öncesi ilişkiler üzerine çekmekte ve önleyici çalışmaların önemini vurgulamaktadırlar. Yurtdışında uzun yıllardır evlilik öncesi eğitimlerin uygulandığı ve yaygınlaştığı görülmektedir. Ülkemizde de evlilik öncesi dönemin çift ilişkileri üzerindeki etkisi ve önemi anlaşılmış olup Bakanlık düzeyinde evliliğe hazırlanan çiftlere yönelik uygulamaların başlatıldığı görülmektedir. Aynı zamanda, son yıllarda farklı üniversitelerde konuyla ilgili deneysel çalışmalara dayanan bilimsel araştırmaların yapılmış olduğu gözlemlenmektedir. Uygulamaların artması, genç bireylerin evlilik ve aile yaşamına hazırlanmalarında etkili olacak eğitim programlarının nasıl değerlendirileceği 
konusunu düşündürmektedir. Bu programların etkililiğini değerlendirmede kullanılabilecek bilimsel, geçerli ve güvenilir ölçme araçlarının gerekliliği ortaya çıkmaktadır. Türkiye' de yapılan çalışmalar incelendiğinde, evlilik öncesi eğitimlerin etkililiğinin değerlendirilmesinde kullanılabilecek geçerliği ve güvenirliği test edilmiş sınırlı sayıda ölçme aracı olduğu görülmektedir.

\section{Araştırmanın Amacı}

$\mathrm{Bu}$ çalışmanın amacı, üniversite öğrencilerine yönelik bir Çift İlişkileri Ölçeği geliştirmektir. Çift İlişkileri Ölçeği (ÇïÖ), özellikle evliliğe hazırlık programlarında kullanılabilmesi amacıyla geliştirilmiştir. Bu amaçla yapılan çalışmada, Türk kültüründe geliştirilmiş olan Çift İlişkileri Ölçeği (ÇïÖ) tanıtılmıştır.

Araştırmanın Yöntemi

Çı̇Ö'nün geçerlik ve güvenirlik çalışmaları Hacettepe Üniversitesi'nde öğrenim görmekte olan 1115 üniversite öğrencisi üzerinde yapılmıştır. Çï̈̈́nün geçerliğini sınamak için yapı geçerliği ve benzer ölçekler geçerliği yöntemleri; güvenirliğini sınamak için Cronbach Alpha katsayısı ve testi yarılama yöntemleri kullanılmıştır. Çalışmada kullanılan tüm veriler SPSS programıla analiz edilmiştir. Yapı geçerliği için öncelikle, verilerin faktör analizi için uygun olup olmadı̆̆ını incelemek amacıyla, KMO değerinin .60 'dan yüksek, Barlett testinin anlamlı çıkması gerektiği dikkate alınmıştır. Verilerin faktör analizi için uygun çıkması üzerine ölçeğin faktör yapısı ve maddelerin faktör yükleri Açımlayıcı Faktör Analizi ile incelenmiştir. Faktörleştirme tekniği olarak da temel bileşenler analizi seçilmiştir. Analizlerde faktörlerin her bir değişken üzerindeki ortak faktör varyansı, maddelerin faktör yükleri, açılanan varyans oranları incelenmiştir. Faktör yapılarının belirlenmesinde, maddelerin .30 ve üzerinde faktör yük değerlerine sahip olması bir kriter olarak alınmıştır. Component Matriks tablosunda birinci faktörde maddelerin faktör yüklerinin .30 ve üzerinde olması ile her alt ölçeğin aynı zamanda tek boyutlu olması ve toplam puanının kullanılabilmesi esas alınmıştır. Birbiriyle ilişkili maddelerin bir araya gelerek faktör oluşturması ve faktörlerin daha kolay yorumlanabilmesi amacıyla Varimax eksen döndürme tekniği seçilmiştir. İnceleme sonunda birinci faktörde faktör yük değerleri .30' dan düşük çıkan, faktör yük değerleri farklı faktörlerde birbirine yakın olan, ayırt ediciliği düşük olan ve diğer ölçek maddeleri ile düşük korelasyon veren maddeler ölçeklerden çıkarılmıştır. Faktör analizi sonrasında, ÇiÖ'nün 5 alt ölçekli, 78 maddeden oluşan formu elde edilmiştir. ÇïÖ'de İletişim, Romantizm-Cinsellik, Çatışma Çözme, Sosyal Destek, Farklılıkları Kabul adında beş alt ölçek bulunmaktadır. Elde edilen form üzerinden ölçeğin sözü edilen diğer geçerlik ve güvenirlik çalışmaları yapılmıştır.

Araştırmanın Bulguları

Faktör analizi çalışmalarına göre, İletişim alt ölçeği 6 faktörlü bir yapı göstermekte ve toplam varyansın \% 64,2'sini açıklamaktadır. Romantizm-cinsellik alt ölçeği için 5 faktörlü bir yapı göstermekte ve toplam varyansın \% 61,5'ini açılamaktadır. Çatışma Çözme alt ölçeği 5 faktörlü bir yapı göstermekte ve toplam varyansın \% 60,1'ini açıklamaktadır. Sosyal Destek alt ölçeği için 2 faktörlü bir yapı göstermekte 
ve toplam varyansın \% 63,3'ünü açıklamaktadır. Farklılıkları Kabul alt ölçeği 5 faktörlü bir yapı göstermekte ve toplam varyansın \% 60,7'sini açıklamaktadır. Çı̇Ö'nün Evlilik Öncesi İlişkileri Değerlendirme Ölçeği ile benzer ölçekler geçerliği sonuçları değerlendirildiğinde; 181 üniversite öğrencisinden alınan verilere göre, iki ölçek arasında pozitif yönde ve manidar düzeyde. 824'lük bir korelasyon saptanmıştır. ÇïÖ’nün güvenirlik çalışması sonuçları değerlendirildiğinde, Çi̇Ö'nün tüm alt ölçekleri için Cronbach Alpha güvenirlik katsayıları, İletişim alt ölçeği için .77; Romantizm Cinsellik alt ölçeği için .88, Çatışma Çözme alt ölçeği için .85, Sosyal Destek alt ölçeği için .91, Farklılıkları Kabul alt ölçeği için .79 olarak bulunmuştur. Çi̇Ö́nün testi yarılama yöntemiyle incelenen testi yarılama katsayıları, İletişim alt ölçeği için .61; Romantizm Cinsellik alt ölçeği için .64, Çatışma Çözme alt ölçeği için .73, Sosyal Destek alt ölçeği için .69, Farklılıkları Kabul alt ölçeği için .64 olarak bulunmuştur.

\section{Araştırmanın Sonuçları ve Öneriler}

Çı̇Ö'nün maddeleri alt ölçek biçiminde gruplandırılmıştır. İletişim alt ölçeğinde 15 madde, Romantizm- Cinsellik 18 madde, Çatışma Çözme 18 madde, Sosyal Destek 12 madde ve Farklılıkları Kabul 15 madde olmak üzere Çi̇Ö'de toplam 78 madde bulunmaktadır. Her alt ölçekte tersine çevrilmiş (reverse) maddeler bulunmaktadır. Ölçek üçlü derecelendirmeli (bana tamamen uygun =3 ile bana hiç uygun değil=1) olup bireyler maddelerin karşısındaki parantezin içine çarpı işareti koyarak tepkide bulunmaktadırlar. Düz maddeler, olduğu gibi, tersine çevrilmiş maddeler ise tersinden puanlanmaktadır. Ölçeklerin puan aralıkları şöyledir: İletişim: 15-45, Romantizm- Cinsellik: 18-54, Çatışma Çözme: 18-54, Sosyal Destek: 12-36, Farklılıkları Kabul: 15-45, ÇïÖ (toplam): 78-234. Yüksek puan, bireyin o alt ölçek boyutunda çift ilişkilerinin daha olumlu düzeyde olduğu anlamına gelmektedir.

Geçerlik ve güvenirliğine ilişkin elde edilen kanıtlar, ÇïÖ’nün yüksek öğretim öğrencilerinin çift ilişki düzeylerini ölçmek amacıyla geçerli ve güvenilir olarak kullanılabileceğini göstermektedir. Evlilik öncesi psikolojik danışma programları ve evliliğe hazırlık programları uygulayanlar programların etkililiğini değerlendirmede Çı̈Ö'yü kullanabilirler. Ayrıca çift ilişkilerinde sorunlar yaşayan öğrencilerin belirlenmesi ile, üniversite psikolojik danışma ve rehberlik merkezlerinden bireysel ve grupla psikolojik danışma yardımı almalarının sağlanması faydalı olabilir. Çı̇Ö́yü başta psikolojik danışmanlar, çift ve aile danışması alanında uzmanlar, psikologlar, psikiyatristler, sosyal hizmet uzmanları ve araştırmacılar da kendi amaçları doğrultusunda kullanabilirler. Özellikle, çift terapisi alanında uzmanlığı olanlar, terapi sürecini yürütmede ölçek sonuçlarından yararlanabilirler.

Anahtar Sözcükler: Çift ilişkileri, evlilik öncesi ilişkiler, evlilik öncesi psikolojik danışma, evliliğe hazırlık programları 
